Prepared in Cooperation with

Southwest Florida Water Management District

\title{
Regression Analysis of Stage Variability for West-Central Florida Lakes
}

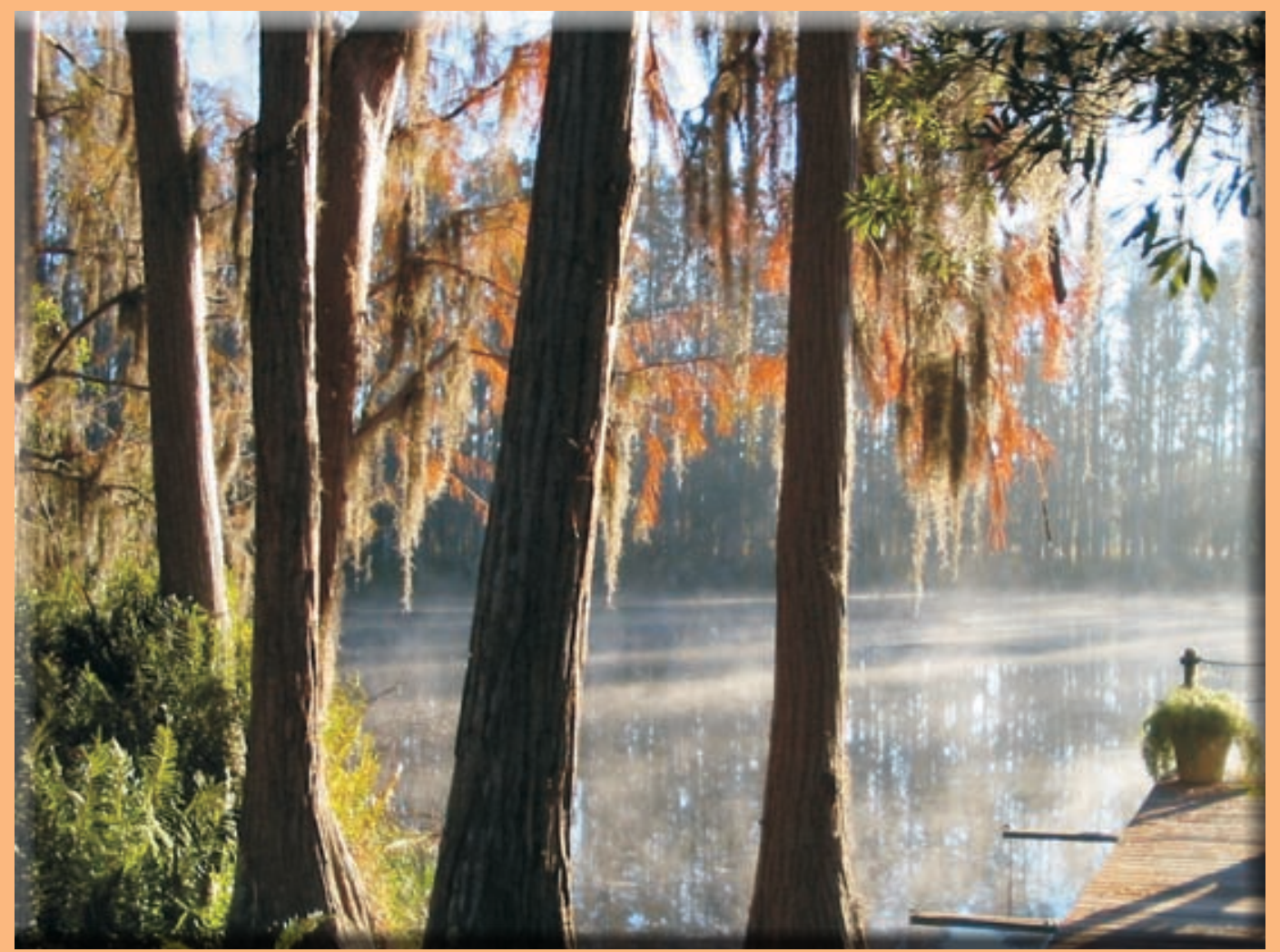

Scientific Investigations Report 2008-5147 


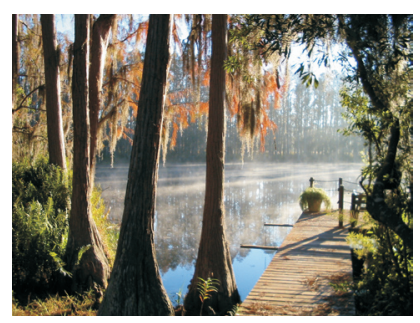

Cover photo-

Photograph taken by Dan Duerr, USGS

Dead Lady Lake, December 27, 2005 


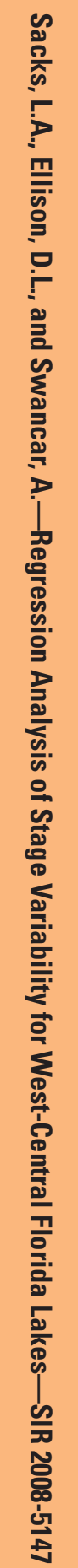

